\title{
Defensive Enforcement: Human Rights in Indonesia
}

\author{
Irene Istiningsih Hadiprayitno
}

Published online: 6 October 2009

(C) The Author(s) 2009. This article is published with open access at Springerlink.com

\begin{abstract}
The objective of the article is to examine the human rights enforcement in Indonesian legal and political system. This is done by studying the legal basis of human rights, the process of proliferation of human rights discourse, and the actual controversies of human rights enforcement. The study has the effect of highlighting some of the immense deficits in ensuring that violations are treated under judicial procedure and the protection of human rights is available and accessible for victims. The author inevitably came into a conclusion that the openness of legal and political arenas for human rights discourses is not followed with a tangible impact on the entitlement positions of the people. The problems of the weak institutions and the unenthusiastic enforcement show that, in Indonesia, human rights are formally adopted as a political strategy to avoid substantial implementation.
\end{abstract}

Keywords Human rights enforcement · Politics of human rights in Indonesia

\section{Introduction}

After the collapse of the New Order regime in 1998, the transition of government left the Indonesians with simultaneous challenges of economic, social, and political changes. Reformasi total or total reform was demanded along with the weakening of military control, the awakening of civil society organizations, and appreciation for the rule of law and human rights. New laws and regulations on human rights were adopted into the legal system. Subsequently, in October 2005, Indonesia adopted and

I. I. Hadiprayitno ( $\bowtie)$

Law and Governance Group, Wageningen University and Research Centrum,

Wageningen, the Netherlands

e-mail: irene.hadiprayitno@wur.nl 
ratified international covenants, the International Covenant on Civil and Political Rights and the International Covenant on Economic, Social and Cultural Rights. ${ }^{1}$ This positive development helped creating a good image for the government, adding Indonesia to the list of nations committed to upholding human rights. ${ }^{2}$ At the praxis level, this progress provides the Indonesians with legal and political opportunities to assert their entitlements according to universal human rights standards.

The new formal commitments in human rights might provide the Indonesians with legal and political opportunities to assert their entitlements according to universal standards. They might offer more possibilities for victims and bystanders to claim protection and compensation. Yet, the main problem of human rights is that these rights have been merely proclaimed but not genuinely implemented. Too often human rights have no actual effect in protecting the right-holders and tend to be disguised in the general euphoria of human rights meetings, committees, declarations, and so forth (De Gaay Fortman 2006, p. 263). Hence, it is necessary to carefully examine processes of implementation, entailing an analysis of the basics as well as the actual dynamics of such processes.

This article aims to examine the human rights enforcement in the Indonesian legal and political systems. While applying an interdisciplinary analysis, it argues that the implementation of human rights in Indonesia entails more than official acknowledgements of human rights discourses. It demands an ideal environment where those rights have already been adequately acquired, and where society functions in a way that enables rights to be realized. This implies a well-functioning legal system and a socio-political culture in which human rights have been well received. Accordingly, claims that are based on entitlements connected to these rights get honored and there is judicial machinery that provides remedies and compensation for victims of human rights violations.

\section{Methodological Observation of Human Rights}

\section{Human Rights as Legal Resources}

Human rights as legal resources is the traditional way of looking at human rights as protection of human dignity by means of law. The approach is made possible because of the formal setting at international (such as United Nations) or national levels are authorized to declare such rights. The context provides legitimacy in efforts to create more than mere acceptance of the right in the international community, but also de facto implementation (Habermas 2001, p. 113).

The construction process of a right contributes to its legal nature, implying the ways and means in which it relates towards rules and procedures. In this respect,

\footnotetext{
${ }^{1}$ The International Covenant on Civil and Political Rights is ratified and adopted by Law No. 12 of 2005 on the Ratification of the International Covenant on Civil and Political Rights. The International Covenant on Economic, Social and Cultural Rights is ratified and adopted by Law No. 11 of 2005 on the Ratification of the International Covenant on Economic, Social and Cultural Rights.

${ }^{2}$ Indonesia was re-elected as a member of the UN Human Rights Council for the period 2007-2010, receiving the second highest number of votes. In terms of international human rights diplomacy, this was certainly a confirmation of success for the government.
} 
Habermas emphasizes first pragmatic discourses that initiate legitimate law-making (Haberman 1996, p. 159). This is followed by a bargaining process and a moralpolitical process in which ethical questions ${ }^{3}$ are debated and the universal values are tested on which the right is supposed to be based. It is the values and goals regarding human rights that had to be put to the test of universality. Once such a test succeeds, it will terminate at the level of juridical discourse in which the final outcomes will be in the form of resolutions concerning legal programs and policies formulated in legal language.

The democratic transcendence from pragmatic ideas and moral discourses to formal legality, which occurred during the formulation stage, serves as a substantial legitimization with regard to human rights as legal instruments. The trajectory sustains and cultivates the construction and outcome of a positive right. It implies the orientation towards rules and regulation that function as modern law. This is why consultations in the proliferation or adoption of human rights become important. Pragmatic questions raised and considered during the consultation process reflect rational thought processes and suggest intended objectives. That activity shall perform as a political and legislative exercise that will define the substance and scope of protection. The exercise would eventually indicate the proneness of the agents responsible for implementation to abide to human rights discourse because they consider it legitimate, not because they are sanctioned when they do not follow them (Diehl et al. 2003, p. 52).

Moreover, human rights acquire the character of legal resources intended to function as law of coercion. Such legitimization in the process of construction of a right facilitates its implementation and enforcement. It implies there are corresponding duties, whose significance in concrete situations influences the enforceability of human rights (Raz 1984, p. 5). In this regard, the states as dutybearers must guarantee further legitimate law-making and de facto enforcement (Habermas 2001, p. 115). Through follow-up rules and regulations and through penalties, if necessary, states must ensure compliant behavior. Furthermore, they have to create enabling conditions for the realization of human rights. ${ }^{4}$ These are commonly categorized as three state obligations to human rights: obligation to respect, obligation to protect, and obligation to fulfill.

\section{Human Rights as Political Instruments}

As political instruments, human rights are regarded as standard of legitimacy on the basis of which the right-holders may challenge any execution of power that violates the freedoms and entitlements incorporated in formal legal documents. The rightholders can activate the entitlements by necessarily connecting them to the presentation of claims. Claims may be defined as calls for the acceptability of something that is admittedly contestable (White 1984, p. 115). Notably, rights do not function as automatic guarantees, but rather as instruments of mediation and

\footnotetext{
${ }^{3}$ Ethical reasoning adopts a collective perspective or an individual perspective. At this level, those goals and values that are raised during the pragmatic discourse are reassured, confirmed, or filtered. Results of ethical and bargaining processes should be put to the test of moral discourses. Ibid, p. 160.

${ }^{4}$ Ibid.
} 
negotiation of claims (Annaim 1998, p. 8). In this connection, the primary responsibility for their implementation rests with the right-holders. They are the primary actors who can act and present claims based upon their presumed entitlements.

Human rights as political instruments refer to the act of making a justified requirement by the right-holder upon the duty-bearers and enjoyment of the possible advantage (Halpin 1997, p. 90). It corresponds to the freedom of creating an act based on the legal nature of a right that justifies the process and the relevant outcomes. Society in this regard is expected to function in such a way that rights are respected whilst claims based on entitlements connected to those rights are also honored (de Gaay Fortman 2003, p. 156).

Thus, the practical application in individual or collective action of human rights is the main concern. Contrary to regarding the human rights as legal resources, this cannot simply be deduced from internationally declared standards (De Gaay Fortman 2003, p. 158). Such perceived human rights entitlements are to be determined inductively in communication with the right-holder themselves. Action-oriented perceptions may advance human rights not merely as rules and regulations of coercion. This enlivens the enforcement of human rights particularly in transitional situations, in which judicial coercion is likely neither yet to be established, nor would it have much effect. Therefore, in collective action based on human rights, claims relating to required entitlements will be expressed as a forceful moral rhetoric, with a political case-by-case approach.

Furthermore, considering human rights as political instruments is a relevant response to the debate between human rights and Asian values. The so-called Asian values perspective still proves a useful reference point when considering the cultural relativism of human rights as a championing viewpoint which Asian countries rely when defending against the universalism of human rights, as well as a justification for the shortcomings of human rights practices. It can be summarized as having the following major components: a relativistic approach to human rights; a communitarian outlook; a strong emphasis on the family; an acknowledgement of economic, social, and cultural influences; and an identified correlation between rights and duties, and emphasis on national sovereignty (Ignatieff 2001, pp. 62-63; Ghai 2000, p. 16-25).

Here, human rights may function as powerful instruments that enable the rightholders to assimilate the local values and the international discourse of human rights. By such activation, their function is not merely protective but also transformative. Moreover, employing human rights as instruments against injustices or nonfulfillment, yet sometimes unsuccessful, certainly has empowered bystanders and victims. In this regard, the argument of different values of human rights, hence might not work in some Asian countries, is rather of limited usefulness. On the contrary, activating human rights discourse as political instruments substantiates possible struggles based on diverse modalities and in different contexts. As a result, human rights are not merely been internationally declared but also they are already historically acquired.

The complexities of employing human rights as both legal resources and political instruments can be demonstrated with the situation in Indonesia after the collapse of 
the New Order in 1998, which opens a different political context that creates modalities and opportunities for implementation.

\section{Human Rights in the Indonesian Legal System}

The Indonesian legal system is based on Pancasila, ${ }^{5}$ the grand norm in Indonesian positive law. Consisting five distinct principles, Pancasila is aimed to define the basic values of Indonesian society in the political culture. Particularly related to human rights, the second principle (Sila Kemanusian yang Adil dan Beradab) is the key reference to the country's commitment to human dignity and human rights. It is variously described as a commitment either to internationalism or more literally to a just and civilized humanitarianism (Morfit 1981, p. 840). Following Pancasila, the Indonesian Constitution (Undang-Undang Dasar 1945) ${ }^{6}$ functions as the source of all laws and regulations concerning all aspects of the nation's life, ranging from government and citizens and their relations to each other to state organs or institutions and their relation to individual lives.

Following the collapse of the New Order regime, Indonesia had one of the most tumultuous years in its modern history: ethnic conflict and economic collapse spurred student-led demands for political reform. His successor, former Vicepresident Habibie, tried to distance himself from his patron by releasing political prisoners, lifting political controls, and, more importantly, building a new system of human rights by amending the 1945 Constitution and adopting the Human Rights Law. The effort has been continued by the following presidents too. In 2000, President Abdurakhman Wahid adopted the Human Rights Court Law and, as mentioned earlier, in 2005 President Susilo Bambang Yudhoyono ratified both international human rights covenants.

In the fourth amendment of the 1945 Constitution, ${ }^{7}$ the range of human rights protection was expanded. Article 28 of the amended Constitution is devoted solely to human rights principles. This article guarantees the universally accepted human rights, namely the right to freedom of assembly, ${ }^{8}$ the right to life, ${ }^{9}$ the right to establish a family, ${ }^{10}$ the right to personal development, ${ }^{11}$ the right to be treated

\footnotetext{
5 The word Pancasila is derived from two Sanskrit words, "panca" meaning five, and "sila" meaning principles. Pancasila constitutes principles of belief in one god, humanitarianism, national unity, consensual democracy, and social justice. These five principles were announced by Sukarno in a speech known as "The Birth of the Pancasila", which he held in front of the Independence Preparatory Committee on June 1, 1945.

${ }^{6}$ The UUD'45 consists of the preamble (Pembukaan), the body of the Constitution (Batang Tubuh) containing 37 articles, 16 sections, and four transitional provisions, two additional provisions, and the elucidation of the Constitutions (Penjelasan Resmi UUD'45, the explanatory notes relating to each of the articles). The preamble, the body, and the elucidation are regarded as one inseparable whole. Thus, when one speaks of the Indonesian Constitution, one speaks of these three components.

7 The 1945 Constitution has been amended four times: October 1999, August 2000, November 2001, and August 2002.

${ }^{8}$ Article 28 of the Fourth Amendment 1945 Constitution.

${ }^{9}$ Article 28 A of the Fourth Amendment 1945 Constitution.

${ }^{10}$ Article 28 B of the Fourth Amendment 1945 Constitution.

${ }^{11}$ Article $28 \mathrm{C}$ of the Fourth Amendment 1945 Constitution.
} 
equally before the law, ${ }^{12}$ the right to work and employment, ${ }^{13}$ the right to religion and freedom to express opinion, ${ }^{14}$ the right to information, ${ }^{15}$ freedom from torture and inhuman and degrading treatment, ${ }^{16}$ the right to a healthy environment, ${ }^{17}$ and the right to be free from discriminative treatment. ${ }^{18}$ Equality before the law, the protection to the freedom of religion, and the right to education remain in the similar texts in Article 27, Article 29, and Article 31, respectively.

One of the most important developments in human rights promotion in Indonesia is the establishment the national human rights law. In the Human Rights Law No. 39 of 1999, the definition of human rights is provided as follows: ${ }^{19}$

'... a set of rights bestowed by God Almighty in the essence and being of humans as creations of God which must be respected, held in the highest esteem and protected by the state, law, Government, and all people in order to protect human dignity and worth.'

The Human Rights Law adopts the principle of equality and non-discrimination, ${ }^{20}$ the principle of indigenous rights, ${ }^{21}$ but not the principle of self-determination (Hosen 2002, p. 61). This law protects equality rights, ${ }^{22}$ right to life, ${ }^{23}$ right to justice, ${ }^{24}$ right to freedom of the individual with regard to slavery, ${ }^{25}$ religious right, ${ }^{26}$ political beliefs, and freedom of speech. ${ }^{27}$ With regard to economic, social, and cultural rights, a wide range of internationally recognized rights are also guaranteed by this law here, such as the right to property and ownership, ${ }^{28}$ the right to work, ${ }^{29}$ and the right to education. ${ }^{30}$

Both the Indonesian Constitution and the Human Rights Law No. 39 of 1999 recognize the concept of human responsibilities. Paragraph $\mathrm{J}$ of Article 28 stipulates that 'in exercising her/his rights and freedoms, every person shall have the duty to accept the restrictions established by law for the sole purposes of guaranteeing the recognition and respect of the rights and freedoms of others and

\footnotetext{
12 Article 28 D (1) of the Fourth Amendment 1945 Constitution.

${ }^{13}$ Article $28 \mathrm{D}(2)$, the right to work is also guaranteed in article 27, paragraph 2 of the Fourth Amendment 1945 Constitution.

${ }^{14}$ Article $28 \mathrm{E}$ of the Fourth Amendment 1945 Constitution.

${ }^{15}$ Article $28 \mathrm{~F}$ of the Fourth Amendment 1945 Constitution.

${ }^{16}$ Article 28 G (2) of the Fourth Amendment 1945 Constitution.

${ }^{17}$ Article $28 \mathrm{H}$ (1) of the Fourth Amendment 1945 Constitution.

${ }_{18}$ Article 28 I (2) of the Fourth Amendment 1945 Constitution.

19 Article 1 (1), Law No. 39 of 1999.

${ }^{20}$ See article 1 (3), 2, 17, 38, 38 (3), 45, 46, and 49 of the Law No. 39 of 1999.

${ }^{21}$ Article 6 of Law No. 39 of 1999.

22 Articles 3, 4 and 5, of Law No. 39 of 1999.

${ }^{23}$ Article 9, of Law No. 39 of 1999.

${ }^{24}$ Articles 17, 18, and 19, of Law No. 39 of 1999.

25 Article 20, of Law No. 39 of 1999.

26 Article 21, of Law No. 39 of 1999.

27 Articles 23, 24, and 25, see also section eight: right to participate in government, of Law No. 39 of 1999.

${ }^{28}$ Articles 36 and 37, of Law No. 39 of 1999.

${ }^{29}$ Article 38, of Law No. 39 of 1999.

${ }^{30}$ Articles 12 and 13, of Law No. 39 of 1999.
} 
of satisfying just demands based upon considerations of morality, religious values, security and public order in a democratic society'. ${ }^{31}$ In the Human Rights Law, the concept of human responsibilities is addressed in its preamble, ${ }^{32}$ defined clearly in Article $2,{ }^{33}$ and provided with a special elaborated chapter on the same legislation. ${ }^{34}$ The aim of this recognition is considered to be based on the idea of human rights itself: that appointing corresponded duty-bearers requires everyone to take responsibility.

The recognition of the concept of human responsibility demonstrates the importance of relativism in human rights protection in Indonesia. In practice, the National Plan of Action on Human Rights of 1998-2003 explains this in the connection that the promotion and protection of human rights should be inspired by Indonesian values, customs, cultures, and traditions. ${ }^{35}$

There should be balance and harmony ... between the rights of the individual and his responsibility to the community and nation. This is commensurate with the nature of the human being both as individual and social being. Equality and harmony between freedom and responsibility are significant factors in the promotion and protection of human rights. It is commonly acknowledged that human rights are universal and the international community has also recognized and concurred that their implementation is the duty and responsibility of states, taking fully into consideration the various value systems, history, culture, political systems, level of social and economic development, and other relevant factors.

Notably, the balance between both the idea of human rights and human responsibility is crucial in the Indonesian context. ${ }^{36}$ The above text also reveals the argument commonly recognized as the Asian values, where human rights should be implemented by taking consideration of different value systems, history, culture, and so forth. With a long history of suppression of individualism and within the setting of transition towards democracy, one could argue the acknowledgment to human responsibility may be considered as a strategic step to incorporate the human rights discourses in the Indonesian legal system.

With respect to human rights enforcement, the Human Rights Law No. 39 of 1999 regulates that the system of claims and remedies of human rights are the subject of the National Human Rights Court. ${ }^{37}$ The procedure of such court is regulated in the Human Rights Court Law No. 26 of 2000.

\footnotetext{
${ }^{31}$ Article $28 \mathrm{~J}$ (2) of the Fourth Amendment 1945 Constitution.

32 Considerant B of Law No. 39 of 1999, whereas human rights are basic rights bestowed by God on human beings, are universal and eternal in nature, and for this reason must be protected, respected, and upheld, and may not be disregarded, diminished, or appropriated by anyone whosoever.

${ }^{33}$ Article 2, ibid: Human obligations mean a set of obligations which, if not undertaken, would make it impossible for human rights to be executed and upheld.

34 Chapter IV on Human Obligations, of Law No. 39 of 1999.

35 Paragraph 2, Decree of The People's Consultative Assembly, No. 11/MPR/1998 of 25 June 1998 State General Guidelines, Seventh Five Year Development Plan, Indonesia National Plan of Action on Human Rights 1998-2003.

36 Ibid.

${ }^{37}$ See Chapter IX on Human Rights Tribunal, of Law No. 39 of 1999.
} 
The human rights court is a special court within the context of a Court of General Jurisdiction. It is located in a regional capital or a municipal capital and its judicial territory covers the judicial territory of the relevant District Court. It has jurisdiction to hear and rule on cases of gross violations of human rights (genocide and crimes against humanity), ${ }^{38}$ including cases perpetrated by an Indonesian citizen outside the territorial boundaries of the Republic of Indonesia. The law does not have jurisdiction over violations of civil and political rights and/or economic social and cultural rights. So far, there has been one case handled by a permanent human rights court; the trial of the Abepura case took place in Makassar in December 2000.

Cases of human rights violations committed before the enactment of the law fall under the jurisdiction of ad hoc courts. ${ }^{39}$ According to the Decision of Constitutional Court No. 18/PUU-V/2007, the decision whether to employ an ad hoc court to prosecute a particular case needs to consider the results of investigation of the National Commission on Human rights and the Attorney General. Thereafter, the House of Representatives can make recommendations for the issuance of a presidential decree in order to officially establish an ad hoc human rights court.

The approach of using ad hoc courts was opted as a transitional justice mechanism, because the amended 1945 Constitution stipulates a controversial article that inhibits the judicial process of prosecuting past human rights violations. Article 28 I section (1) states 'the right not to be tried under a law with retrospective effect ... cannot be limited under any circumstances'. With this provision, it would be impossible to prosecute those responsible for human rights crimes (crime against humanity and genocide) during the New Order that were not considered crimes under the prevailing Code of Criminal Procedure (KUHAP). Since the 1945 Constitution is placed as the primary law and no other laws or regulations may contravene it, therefore the past gross violation of human rights should be treated under an ad hoc human rights court with consideration to the time and place of the violations. The ad hoc courts can only be established by the President, after a recommendation from the House of People's Representative. Hitherto there have been two ad hoc human rights courts, the ad hoc court for East Timor and the ad hoc court for the Tanjung Priok Massacre.

In terms of judicial procedures of both types of courts, Article 10 asserts that they will be conducted in accordance with provisions in the existing Code of Criminal Procedure (KUHAP). As said before, inquiries into cases of gross violation of human rights are conducted by the National Commission on Human Rights, while the Attorney General is given the power of arrest ${ }^{40}$ and is authorized as the investigator and public prosecutor. ${ }^{41}$

In practice, the employment of the Indonesian Criminal Code as the basis for the procedural law of the (ad hoc) human rights court is observed to be problematic. The establishment of the Criminal Code was not aimed at addressing cases of gross

\footnotetext{
${ }^{38}$ Articles 4 and 7, of Law No. 26 of 2000.

39 Article 43 (1) Law No. 26 of 2000 states that gross violations of human rights occurring prior to the coming into force of this Law shall be heard and ruled on by an ad hoc Human Rights Court.

${ }^{40}$ Article 11 (1), Law No. 26 of 2000.

${ }^{41}$ The Attorney General is also authorized as investigator and public prosecutor '...to undertake the detention or extend the detention of a suspect for the purposes of investigation and prosecution'. Article 11 (2), Law No. 26 of 2000.
} 
violations of human rights that procedurally require more specific provisions with regard to, for example, protection of witnesses and victims or regulation on acceptable means of verification. In respect to the latter issue, the Criminal Code merely includes testimonies, expert statements, official letters and/or documents, hard evidence, and defendants' statements as sufficient. Given to the nature of the cases, the prosecutor would need a wider parameter than these five requirements in order to prove genocide and/or crimes against humanity.

Additionally, there are also problems with a number of provisions in the legislation that have the potential to undermine the independence and impartiality of the judiciary serving in the Human Rights Courts or in related appeals courts. Ad hoc judges are appointed to the Human Rights Courts and, in the case of an appeal, to the High Court by the President on the recommendation of the Supreme Court. ${ }^{42}$ Moreover, in the case of a cassation appeal to the Supreme Court, ad hoc judges are to be appointed by the President on the recommendation of the People's Representative Assembly. ${ }^{43}$ A more specific discussion on the problematic encounters of ad hoc human rights courts will be provided later in this article.

The list of rights stipulated in both the Constitution and the Human Rights Law as well as the establishment of human rights courts demonstrate sufficient modalities of legal resources to guarantee protection of human rights in Indonesia. Therefore, efforts towards implementation could be intensified. As discussed earlier, such legal resources could facilitate enforcement, because it implies that there are corresponding duties. It this sense, the Government of Indonesia is obliged to guarantee real enforcement and to ensure compliant behavior. Yet, in the case of Indonesia, enforcement still depends on many aspects. As revealed, the formulation of the laws considered the issues of balancing responsibilities and rights or cultural background. These issues will be explained in the following sections.

\section{Towards Realization of Human Rights in Indonesia}

Proliferation of Human Rights: Between Ideology, Culture and the International Pressure

The adoption of the discourse into the national context entails a process of proliferation of the discourse of human rights; therefore, they can be incorporated at all areas in the society involving social, cultural, and political issues. In the context of Indonesia, examining the proliferation of human rights involves an understanding of the overall picture of how the discourse is being adopted, in particular the contextual setting where all areas in the society are connected and not isolated.

Many experts have studied how culture, entailing the focus on family values, patron-client relationship, respect, and social harmony, dominates the political structure in Indonesia. ${ }^{44}$ Alongside these, Pancasila has been nurtured and accepted as an ideology effective in maintaining status quo. Particularly during the New Order

\footnotetext{
${ }^{42}$ Articles 28 (1) and 32 (5), the Fourth Amendment of the 1945 Constitution.

43 Article 33 (4), the Fourth Amendment of the 1945 Constitution.

${ }^{44}$ See for example: Budiman (1978); Pye (1999); Bowen (1986); Magnis-Suseno (2001).
} 
era, these values and ideology had successfully suppressed any social unrest and secured the status quo. During this period, the state was organized as a 'family' (Budiman 2005, p. 376; Katjasungkana 2000; p. 263), crowning the president as the head of the family while the citizens were considered as his children. This patronclient relationship has placed the state in the hegemonic position. It was required to respect the head of the family and any actions that could threat the harmony were unwelcomed. $^{45}$ The culture also compels people to mask their real sentiments, practice conformity, and pretend to positions that they do not really hold. The country's political structure strongly emphasized the absence of personal interest in political activity. It gave no room for any individual opinions or objections coming from below. In the political arena, the dominating culture used Pancasila as its ideological vehicle. Human rights are perceived as encouraging the value of individualism, as incompatible with the national ideology Pancasila.

Thereby, people could not substantially use the principle of democracy in relation to, for example, the freedom of expression. Articulating their opinions and objections was considered un-Pancasila because it could risk the harmonious state of the nations. Decisions, which ideally should be made by consensus, was actually meant that although the younger participant called for bold actions, and the middle-aged added their cautious for wisdom, in the end the senior figure usually declared what the "consensus" was whether or not anybody every articulated (Pye 1999; p. 774).

Another factor that influences the proliferation of the human rights discourse in Indonesia is the international pressure. A common example is the human rights violations in East Timor in the 1990s. ${ }^{46}$

At first, the government could partly get away with the rhetoric of 'Asian values', suggesting that human rights had to be seen in their social, economic, and cultural aspects. It worked because the human rights network in Indonesian proper was neither well connected with the East Timor network nor with the transnational human rights network. However, the situation changed after the atrocities of a massacre in Dili in November 1991. Pressures particularly from western foreign aid donors forced the government to move from denial to tactical concession. At the 1992 session of the UN Human Rights Commission, the Indonesian delegate claimed that Indonesia strictly prohibited the practice of torture. From then on, the human rights discourse not only centered on East Timor. The Indonesian government started cooperating fully with the National Human Rights Commission during the 1993-1997 and acknowledged specific human rights violations.

After the resignation of Suharto, international pressures remained to play an important role in paving the pathway for human rights to be incorporated into the Indonesian legal system. Still related to the case of East Timor, the Human Rights Court Law No. 26 of 2000 was adopted partly as a response to the Security Council

\footnotetext{
45 To be Javanese means to be a person who is civilized and who knows his manners and his place. The individual serves as a harmonious part of the family or group. Life in society should be characterized by rukun (harmonious unity). To achieve rukun, persons should be primarily group members; their individuality should be expressed through the group. All overt expressions of conflict should be avoided. Unlike Western culture, which regards individualism and group belonging as mutually exclusive, most Javanese consider the two intimately related (Magnis-Suseno 2001, pp. 38-60).

${ }^{46}$ See in particular Thomas Risse (1999, p. 546).
} 
Resolution No. 1264 of 1999, which calls the Indonesia Government to bring the perpetrators to justice. ${ }^{47}$ The binding nature of this resolution left two options for the Indonesian government: to accept an international tribunal and to establish a national human rights court. To avoid the first option, strong diplomacy efforts was performed by Alwi Shihab, the Foreign Minister of Indonesia at that time, in order to convince the permanent members of the Security Council and the Secretary General to accept the model of ad hoc human rights court to trial the perpetrators in the East Timor case. The enactment of Human Rights Court Law No. 26 of 2000 and the establishment of ad hoc human rights court on East Timor are the evidences of the good results of Indonesian diplomacy and the pungent influence of international pressures. In the domestic politics, the establishment of the ad hoc human rights court was an unprecedented process in a country that had long suffered from extensive and entrenched impunity.

This foregoing description reveals that the proliferation of human rights involved a dialogical process of accepting international pressures. Notably the international pressure had invited the Indonesian government to engage in the argumentative process. Subsequently, it also has opened the political space in the Indonesian society and contributed to the proliferation of the human rights discourse. Human rights groups mushroomed and President Suharto was less and less in control of the domestic situation.

Therefore, one could argue that the official adoption of the human rights discourse is not yet an outcome of a process of emancipation. Subsequently, this trajectory would have some significant effects while translating the human rights discourse into legal provisions or policies. First of all, one can observe that human rights provisions were constantly modified during the four amendments of the 1945 Constitution. Additionally, the government introduced human rights along with the human responsibility. ${ }^{48}$ It is demanded to always consider human responsibility before claiming for human rights. In line with the Asian value rhetoric, human responsibility itself is a principle construed one-sidedly by the state and widely propagated in order to inhibit the potential inclusion of people in the policy-making process. Furthermore, the Law on Human Rights Court No. 26 of 2000, which is the legal basis of the Human Rights Court in Indonesia, includes only crimes against humanity, torture, and genocide, in its jurisdiction, and leaves out the human rights violations related to, for example, freedom of speech, right to food, or right to health.

Interpretation of Human Rights

\section{Civil and Political Rights}

Freedom of speech and freedom of assembly are particularly dominant in the topic of civil and political rights in Indonesia. These entitlements have been acknowledged as important since the country's independence. Even the original version of Article 28 of the 1945 Constitution guaranteed freedom of speech and freedom of assembly. ${ }^{49}$ However, as mentioned before under the Suharto administration, both

\footnotetext{
${ }^{47}$ Para. 1 S/RES/1264 of 1999.

${ }^{48}$ Considerant B of Law No. 39 of 1999.

${ }^{49}$ Article 28, Indonesian Constitution, Fourth Amendment, 2002.
} 
entitlements were systematically restrained. The government imposed additional laws and regulations ${ }^{50}$ that limited the freedom of speech of individuals and the media. In fact, the government used criminal law and the law prohibiting subversion against those exercising freedom of speech against the government (Juwana 2006; p. 371).

After the resignation of Suharto, freedom of speech improved significantly. The Indonesian Press and Publication Society or MPPI (Masyarakat Pers dan Penyiaran Indonesia) was able to initiate a draft of the Law on Freedom of Press at the House of People's Representative. In September 23, 1999, Habibie and the House of People's Representative adopted Law No. 40 of 1999, which guarantees the freedom of press from any government interference. ${ }^{51}$

Consequently, a growing number of new newspapers, magazines, radio, and television stations were established and they can report almost anything without any government censorship. Yet, the improvement in freedom of speech during the Habibie administration was not merely a result of this regulation. Rather, it was because people were no longer afraid of voicing their concerns. The public could express freely almost anything without any anxiety, including sensitive issues. Therefore, freedom of speech was no longer centered only on the liberalization of press and publications, but also the opening of the political lid for everyone to publicly criticize government policies and conducts, something that was out of the question before.

Recently, the discourse of freedom of speech in Indonesia has been dominated by issues of pornography and obscenity in public spaces. The rising quantity and variety of media has induced an increased amount of publications featuring semipornographic pictures and stories. A strong lobby carried by a radical Muslim movement has succeeded in pressurizing the House of People's Representative (DPR) to respond by drafting an anti-pornography law. ${ }^{52}$ The draft of this law defines acts of pornography as actions intended to show and/or to exploit sexual, indecent, and/or erotic activities (Hikmahanto Juwana 2006; p. 374). On 30th October 2008 the DPR passed the Anti-Pornography Law, although two parties were reported to have walked out from the process. ${ }^{53}$ On 9th December 2009, after the authorization from President Yudhoyono, the law was enacted and became Law No. 44 of 2008 on Pornography. ${ }^{54}$

The growing popularity of the issue of pornography occurred simultaneously with the increasing application of Shariah laws by local governments. With the application of the new Local Government Law No. 32 of 2004, it is now possible for the local government to impose laws that are relevant to the need of the area. In some areas, this has been translated as the implementation of Shariah Law in the daily life. Hitherto, this law has disproportionately affected women. In the

\footnotetext{
${ }^{50}$ See: Undang-Undang Pokok Pers No 11/1966, juncto No 4/1967, juncto No 21/1082. All aim to regulate the press and control public opinion.

${ }^{51}$ Article 15 (2 f) of Law No. 40/1999 of 23 September 1999.

52 'Pornography to be allowed for medication, education', The Jakarta Post, 4 September 2003.

53 The two parties are Partai Damai Sejahtera (a Catholic-Christian-based party) and Partai Demokrasi Indonesia Perjuangan (one of the biggest parties in Indonesia). 'Akhirnya RUU Pornografi disahkan', Kompas, 30 October, 2008.

54 'SBY signed porn law, protesters despair', The Jakarta Post, 9 December 2008.
} 
Tangerang municipality alone (in the Province of Jakarta), at least 11 women have been arrested just because they were out at night wearing makeup. ${ }^{55}$ In Aceh, three women activists were arrested by the Shariah police because they were not wearing veils and talking in front of their hotel rooms after a human rights training. ${ }^{56}$

With respect to freedom of assembly, Law No. 9 of 1998 regulates time, place, and manners for holding demonstrations in public places. Although the law provides penalties ranging from dispersal of the assembly to imprisonment for those responsible for the assembly, restriction to forms of assembly such as seminars, group discussions, and academic seminars have been greatly relaxed. ${ }^{57}$ Permits are no longer required; the organizer only needs to inform the police of the activities.

Unfortunately, protests and demonstrations often lead to violent and destructive acts. These cause antipathy and public inconvenience. Demonstrations cause hassles in public infrastructures, such as blocking the highways ${ }^{58}$ and creating traffic problems. Additionally, large-scale demonstrations also give rise to direct confrontation with the police and military which has in the past resulted in casualties and death, such as during the demonstration for the trial of Suharto, where members of the public and university students staged continuous demonstrations. ${ }^{59}$

To summarize, on the subject of the implementation of the civil and political rights, legal incorporation, which actually obliges the state to create an enabling environment for freedom of speech and freedom of assembly, does not bring a culture of different opinions in Indonesia. A real opposition as found in many other countries does not exist and it remains difficult to have access to the policy making. Opposition activities are unorganized and they do not take place in the existing democratic system. They are merely 'street opposition', rather than parliamentary opposition. As a result, issues that acquire strong political support, using the setting of freedom of speech and freedom of assembly, are also limited to those 'safe subjects' such as pornography, rather than more significant subjects aim to empower the right-holders in the political system or claim human rights entitlements.

\section{Economic Social and Cultural Rights}

Similar to its counterpart, economic, social, and cultural rights gained more attention after the resignation of Suharto. In addition to the ratification of the International Covenant of Economic, Civil and Political Rights, popularity can also be observed in

\footnotetext{
55 Article 4 of the Tangerang Regional Regulation No. 5 of 2005 on Prostitution asserts that any women with suspicious behavior can be arrested. This suspicious behavior includes being in public spaces, streets, hotels, dormitories, coffee shops, cinemas, etc. 'Perempuan, Perda dan Domestifikasi', Kompas, 4 March 2006.

56 'Perempuan, Perda dan Domestifikasi', Kompas, 4 March 2006.

57 Article 15 and 17 of the Law 9/1998.

${ }^{58}$ See: Gaji Terlambat, 1.500 Karyawan Texmaco Blokir Jalan Tol Karawang, Koran Tempo, 16/12/2003, Ratusan Karyawan Texmaco Blokir Jalan Tol, Pedoman Rakyat, 16/12/2003, 17, 50 Truk Demo, Jalan Tol Macet Satu Jam, Jawa Pos, 6/8/2000, 1 (Radar Semarang).

${ }^{59}$ In June 18, 1999, students clad in long white robes gathered near Semanggi cloverleaf in Jakarta and began hanging effigies of former president Suharto from trees and setting up blackboards, with slogans demanding that President Habibie bring his predecessor to trial for alleged misdeeds during his administration. John H. McGynn (et al.), Indonesia in the Suharto Years: Issues, Incidents and Images. (Leiden: KITLV, 2005) p. 390.
} 
the growing initiatives taken to promote this set of rights by civil society organizations. This is a different situation when compared with pre-1998 human rights activism, which mostly concentrated on the civil and political rights domains, because this set of rights was considered the most violated one. After the crisis, economic, social, and cultural problems were more evident as well as urgent and therefore gained more attention.

The second reason for the growing awareness of economic, social, and cultural rights results from the effects of the economic crisis on economic and social conditions in Indonesia. The human poverty index (HPI), developed by the United Nations Development Programme (1997), attempts to provide an aggregate measure of capability by combining four indicators, namely life expectancy, adult literacy rate, access to improved drinking water, and proportion of underweight children below the age of five. The estimated HPI for Indonesia was about $34.7 \%$ before the crises but was down to $23.2 \%$ in 2000 (Dhanhani and Islam 2002). The decreasing quality of life triggered civil society organizations to react as violations were easily observed and monitored. They considered especially the problems of hunger, poor employment protection, and vulnerability of the most disadvantaged people to health risks as the most crucial issues in terms of economic, social, and cultural rights in Indonesia.

One particular challenge to the promotion of economic, social, and cultural rights in Indonesia is on the issue of mainstreaming human rights perspectives in economic, social, and cultural laws and policies. Health Law No. 23 of 1992, for example, only provides general guidance for availability of health care in Indonesia, without perceiving health as a part of human dignity. Furthermore, as a human right, health care too should be able to be claimed at the legal level. The absence of this important entitlement is found in other laws related to economic, social, and cultural rights such as the Education System Law No. 2 of 1989 or the Food Security Law No. 7 of 1996 . Notably being adopted by the New Order regime, these laws are no longer relevant to the protection of the right to health, right to education, and right to food stipulated by the Human Rights Law No. 39 of 1999. Nevertheless, so far there have not been any discussions on revising those laws.

The laws adopted after the New Order are also far from perfect, as they are still prone to challenges coming from powerful actors. The Law on Labour Force No. 13 of 2003 is an example. The provisions of the Law that actually benefited workers ${ }^{60}$ are being contested by the Indonesian Business Association (Asosiasi Pengusaha Indonesia or Apindo). The organization is currently demanding a revision to abolish several favorable provisions with regard to salary standards, welfare facilities, compensation calculations, and possibility for workers to conduct protests and demonstrations. In particular, Apindo is proposing the transfer of the obligation of workers' protection in terms of welfare, safety, and health care to the companies rather than the State as had been stipulated in Law No. 13 of 2003 on Manpower. ${ }^{61}$ If these obligations are borne by the companies, companies will also decide the standards. Naturally, this could negatively affect the entitlement positions of the

\footnotetext{
${ }^{60}$ Article 156, Law No. 13 of 2003 on Manpower.

${ }^{61}$ Article 35 (3), Law No. 13 of 2003 on Manpower. Also 'Inilah Revisi UU No. 13 tahun 2003 yang Dianggap Paling Gila', Tempo Interaktif, 29 March 2006.
} 
workers because, as commercial entities, companies are concerned more with profits than with workers' conditions.

Common responses are usually raised by the government when confronted with the subject of economic, social, and cultural rights in Indonesia. The first is related to the question of resources. Although facts have proven that a strong economy state does not automatically deliver a good protection of economic, social, and cultural rights, it is perceived that promoting economic, social, and cultural rights requires allocation of resources. This set of rights is notably dependent on the capability and is claimed to be closely related to the economic situation of the state in question. With respect to Indonesia, this excuse has been repeated by the government in an attempt to redeem their failure to carry out their obligations in promoting and protecting economic, social, and cultural rights. In fact, it is often used to avoid their obligations. Lack of resources is considered rationalization for their non-fulfillment of human rights.

In this regard, the Indonesian government relies on international activism, which means international aid, to globally eradicate poverty that infringes the fulfillment of economic, social, and cultural rights. Such a view is reflected in the statement of the Indonesian delegation before The Fourth Session of the Permanent Forum on Indigenous Issues on agenda item "Eradicate Extreme Poverty and Hunger", stating that: "poorer countries should be able to look forward to reliable international support as a means to create employment and bring about economic growth in general, in response to the challenge of poverty., ${ }^{62}$

Nonetheless, fulfillment of economic, social, and cultural rights is not only about resources. This is only part of the obligation to fulfill ${ }^{63}$ of the State Party related to this set of rights. The obligation to protect primarily depends on favorable adopted policies that actually aim at protecting the entitlement of economic, social, and cultural rights, while obligation to respect requires the Government of Indonesia to refrain from adopting laws that are depriving the right-holders from accessing their right. The deficits of the laws described before demonstrates that efforts towards fulfilling the last two obligations are still lacking.

Moreover, international organizations, the place where the resources are allegedly expected, cannot be expected to alter national policies. In fact, economic, social, and cultural rights depend on the identification of the non-fulfillment of human rights entitlements made by domestic actors, particularly non-governmental organizations, the media, and right-holders. Furthermore, the decision making of policies should involve people who have the clearest standing to insist on a particular allocation and who are usually the residents of the country in question (Roth 2004; p. 65). These groups can at the same time act as pressure groups to seek claims and remedies from the violation of economic, social, and cultural rights.

The lack of protection to people's entitlements on economic, social, and cultural rights aggravates as Human Rights Court Law No. 26 of 2000 does not have the jurisdiction over the economic, social, and cultural rights. Hence, although the 1945

\footnotetext{
${ }^{62}$ Statement by Mr. Dicky Komar, First Secretary, before The Fourth Session of The Permanent Forum on Indigenous Issues on Agenda Item $3 \mathrm{~A}$ - Goal 1 of the Millennium Development Goals: "Eradicate Extreme Poverty and Hunger" New York, 18 May 2005, http://www.indonesiamission-ny.org/NewStatements/ 3c051805_indigi.htm, retrieved September 7, 2007, at 14.39.

${ }^{63}$ Typology of obligations of the State under ICESCR: Obligation to Respect, Obligation to Protect, and Obligation to Fulfill. See Sepulveda (2003).
} 
Constitution and the Human Rights Law No. 39 of 1999 guarantees protection to human rights, the enforcement of these rights is practically problematic. The laws indeed serve as revealing violations, but without the possibility of claims and compensation the Indonesian government could continue to concentrate on the number of generic fulfillments, measured by numbers. Consequently, it becomes difficult for the human rights institutions, officials, or civil society organizations to interfere when there are certain errant practices, for example, the unfair house eviction or the problem of hunger.

\section{Actual Controversies in Human Rights Enforcement}

To examine the translation of human rights discourse in legal and political arenas, this section discusses the actual controversies with regard to National Commission of Human Rights as one of the prominent actors in human rights implementation; the Ad Hoc Human Rights Court of Tanjung Priok to demonstrate the struggle against impunity; the issue of corruption that lingers the promotion of human rights through judicial system; and the roles of civil society and collective actions.

\section{Effectiveness of the National Commission on Human Rights}

As a surprising initiative to protect human rights, Suharto adopted Presidential Decree No. 50 of 1993 to establish the National Commission on Human Rights (or also popularly known as Komnas Ham) as an institution responsible for the situation of human rights in Indonesia. ${ }^{64}$ Requirements of external diplomacy ${ }^{65}$ in a changing international politics, particularly the end of the Cold War, were cited as prime reasons for its establishment (Wanandi 1993; p. 14-37). The establishment of the Commission was aimed to prepare the Government for the International Human Rights Convention in Vienna 1993 (Pratikno and Lay 1999; p. 7).

This background prompted skepticism about the Commission's likely effectiveness. Commission membership appeared to be dominated by Suharto era appointees and was insufficiently diverse in terms of gender, region, and social backgrounds.

According to Presidential Decree No. 50 of 1993, the Commission's mandate was guided by Pancasila and the Indonesian Constitution. It had four primary areas of concern: (1) spreading awareness of human rights both nationally and internationally, (2) considering United Nations human rights instruments in order to make suggestions on accession and ratification, (3) monitoring and investigating human rights practices and providing opinions and suggestions to the Government, and (4) encouraging regional and international cooperation in the promotion and realization of

\footnotetext{
${ }^{64}$ The History of this institution began in 1993, based on the Presidential Decree No. 50 of 1993, which was the follow-up of a recommendation from the workshop in Foreign Affairs Ministry with the support of United Nations. This human rights legislation particularly addressed the matter of the National Commission on Human Rights' objectives, authority, and some practical matters regarding its board and staff.

65 The Commission was widely thought to be a response to the intense international pressure mounted on the Indonesian Government in the wake of the 1991 massacre in East Timor, where security forces shot and killed over 200 demonstrators.
} 
human rights. The decree, however, did not empower the Commission to undertake investigations into human rights violations, request technical assistance in investigations, hear or consider complaints, subpoena witnesses or documents, visit jails or prisons, or file information with the courts. On paper, it appeared as though the National Commission on Human Rights had little power to affect change in Indonesia.

Moreover, the critics pointed to contradictions in the Commission's composition, structure, and operating style that weakened its effectiveness. One fear was that because the Commission was established by decree and was not grounded in a higher law it could notably be dissolved at any time by the President. Furthermore, the Government funded the Commission and there were no mechanisms in place to prevent the Government from restricting or influencing the Commission's activities. There were no legal safeguards to protect the Commission's integrity and independence. The 21 Commission members were selected by Suharto himself and many had ties to prior human rights violations by the Suharto regime. These appointments called into question the impartiality of Commission members. ${ }^{66}$

Nevertheless, the Commission unexpectedly delivered critical reports and began to contribute significantly toward increasing public awareness and legitimacy of human rights issues. In 1995, they established an office in East Timor and conducted several inquiries into human rights abuses; this was followed by the release of unexpected findings in a few cases. For example, in March 1995, the Commission reported information that contradicted enquiries being circulated by Indonesian military (Angkatan Bersenjata Republik Indonesia or ABRI) regarding the deaths of six people in East Timor. ABRI claimed that these people were suspected guerrilla members of the Revolutionary Front for an Independent East Timor (Fretelin), ${ }^{67}$ but the Commission concluded that the six were actually non-combatants and they had been intimidated and tortured by the ABRI before they were killed.

Post 1998, the Government upgraded the status of the Commission in promoting human rights in Indonesia. Law No. 26 of 2000 on Human Rights Courts designates the Commission as an institution with the competence to perform pro justicia investigations on gross violations of human rights in Indonesia. In this respect, the Commission may establish an ad hoc inquiry team for every case of alleged gross violation of human rights. ${ }^{68}$ Furthermore, Law No. 39 of 1999 on Human Rights

\footnotetext{
${ }^{66}$ A serious concern arose in 1996, when the Commission announced that only current Commission members would be nominated for the position of chairman. Students protested the proposed internal nominations, arguing that more independent, public figures should be nominated. The internal nominations became effective in October 1996, with the election of Manawir Sjadzali to the chairmanship. Although the Government did not respond specifically to the student's demands, it allotted additional staff members to facilitate the work of the Commission.

${ }^{67}$ The Revolutionary Front for an Independent East Timor (Portuguese: Frente Revolucionária de TimorLeste Independente or Fretelin) is a leftist political party in East Timor. They presently hold a plurality of seats in the National Parliament and they formed the government in East Timor from independence until 2007. The party began as a resistance movement that fought for the independence of East Timor, first from Portugal and then from Indonesia, between 1974 and 1998. It was originally called the Timorese Social Democratic Association (ASDT). After East Timor gained its independence from Indonesia, FRETILIN became one of several parties competing for power in a multi-party system.

${ }^{68}$ Information on the Activities of Komnas Ham carried out during the period of September 2006 and August 2007, submitted to the 12th Annual Meeting of the Asia Pacific Forum of National Human Rights Institutions, Sydney, Australia, 24th-27th September 2007, Under Agenda Item: Report of APF Members, p. 2 .
} 
tries to promote the independency of the National Commission on Human Rights. ${ }^{69}$ The Law authorizes the House of Representatives to appoint members from the list drafted by the Commission itself. ${ }^{70}$ Funds depend on allocations by the DPR, plus external technical and financial assistance. One concern is that provisions in Human Rights Law grant the Commission discretion in disclosing information from complainants without their consent, which appears to breach confidentiality provisions in the Paris Principles, i.e., the UN guidelines governing national human rights institutions. ${ }^{71}$

The current criticism of the Commission's impact on the implementation of human rights after the New Order is that it has been less effective than before, particularly with regard to the inability to achieve executive and judicial outcomes. $^{72}$

Their long ago completed pro justicia inquiries in the cases of "Trisakti 1998, Semanggi 1998, and Semanggi 1999", "May Riot of 1998" as well as "Wasior 20012002 and Wamena 2003" have not been receiving any significant response from the side of the Government. The handling of these cases had become stalled as a result of disagreements between Komnas Ham and the Attorney General's Office over investigations. The latter institution is still reluctant to execute formal investigations on these cases. This happens because the Human Rights Law No. 39 of 1999 provides no clear rules on the tasks and authorities of Komnas Ham and the Attorney General in initiating investigations.

The question of effectiveness is related to the membership problem too. In the period 2002-2007, many of the members of the Commission appeared to have strong affiliations with political parties. An example is Sollahuddin Wahid, who was in charge of the investigation of the "May Riot of 1998". In 2004, Wahid resigned from the Commission after he had been appointed as vicepresidential candidate of General Wiranto by the Political Party Golongan Karya ${ }^{73}$ Ironically, General Wiranto was one of the suspects of the "May Riot of 1998". 74

Furthermore, there are also some concerns regarding the capability of the Komnas HAM to promote human rights stipulated in the Human Rights Law No. 39 of 1999. There are several freezed human rights cases because the Human Rights Court Law No. 26 of 2000 merely recognizes the authority of Komnas Ham to investigate cases belong to the gross violations of human rights: crimes against humanity and genocide. Unfortunately, regardless of the many cases on economic, social, and cultural rights as well as civil and political rights are being reported to this institution, there is yet an agenda from the Komnas Ham to propose a revision to the Human Rights Court Law.

\footnotetext{
${ }^{69}$ See Chapter VII on National Commission on Human Rights, the Human Rights Law No. 39 of 1999.

${ }^{70}$ The DPR has recently called for a new list of 36 members to be submitted. Simanjuntak (2002).

${ }^{71}$ Office of High Commissioner of Human Rights, Fact Sheet 19, National Institutions for the Promotion of Human Rights. April 1993; General Assembly, UNGA/RES/48/134 of 4 March 1994, National Institutions for the Promotion of Human Rights, Annex, Principles Relating to the Status of National Institutions.

72 ELSAM, Hak Asasi Manusia Tanpa Dukungan Politik: Catatan HAM Awal tahun 2008. Report, p. 5.

73 "Sollahuddin Wahid Mundur Sebagai Anggota Komnas Ham", Kompas, 12 May 2004.

74 “Sollahuddin defends Wiranto’s Credential”, The Jakarta Post, 12 May 2004
} 


\section{Ad Hoc Human Rights Court of Tanjung Priok}

As mentioned before, one of the past human rights violations that is being processed under the Law on Human Rights Court No. 26 of 2006 is the 1984 Tanjung Priok Massacre case. The case was undoubtedly the worst mass killing to occur in Indonesia, apart from the killings in East Timor during the Suharto era. ${ }^{75}$

Previously, it has been discussed that, after the collapse of the New Order, the balance of power shifted towards the Habibie camp. Pressures from the Islamic scholars, drawn mainly from the Association of Indonesian Islamic Intellectuals and the Council of Islamic Missionaries, were helpful in bringing the case to the attention of the public (Sulitiyanto 2007; p. 78). Additionally, voices from victims and various Islamic organizations, backed up by many political leaders and prominent figures, added to the number of pressures to re-investigate the case. In 1998, Sontak (the National Solidarity for the Tanjung Priok Event in 1984), together with a group of lawyers from the Association of Defenders of Islam (API) and about 30 witnesses, came to the National Commission on Human Rights, handing over a report with detailed information about the killings which could be used to bring the case to court. After a complicated political procedure, including an establishment of an Ad Hoc Team of Investigation on the Tanjung Priok case (KPP HAM Tanjung Priok-Komisi Penyelidikan Pelanggaran Hak Asasi Manusia Tanjuk Priok), in April 2001, President Abdurakhman Wahid issued Presidential Decree No. 53 of 2001 on the establishment of Ad Hoc Human Rights Courts on East Timor and Tanjung Priok. This decree was later revised by Presidential Decree No. 96 of 2001 issued by Megawati Sukarnoputri that emphasizes the location and the time factors (locus and tempus delicti) of the atrocities that occurred in Tanjung Priok on September 1984.

The Ad Hoc Human Rights Court on Tanjung Priok commenced their first hearing on September $15,2003 .^{76}$ All of the defendants were indicted for crimes against humanity as stated in the Law on Human Rights Court No. 26 of 2000. All of them are the low and middle military ranking officers who were brought to trial, many of whom were on the ground when the killing happened (Sulitiyanto 2007, loc.cit., p. 86). Prominent figures such as General (retired) Try Sutrisno and former Armed Forces Commander General (retired) L.B. Murdani escaped the trial. Naturally, this has brought immediate public criticism and even cynicism, but it did not stop the Court. The overall duration of the trials took about a year, ending in August 2004.

The Ad Hoc Court came with a decision to sentence defendants Sutrisno Mascung CS with 2 and 3 years ${ }^{77}$ and Rudolf Adolf Butar Butar with 10 years in prison. ${ }^{78}$ The other defendants were released. Notably, this ruling is unsatisfactory because under the Law No. 26 of 2000, soldiers, if found guilty, face a minimum of 10 years in prison and a maximum sentence of death. ${ }^{79}$ The Ad Hoc Court has also

\footnotetext{
${ }^{75}$ For the chronology of the Tanjung Priok event, see for example: 'Tanjung Priok acquittals a Travesty of Justice', TAPOL Press Release, July 14, 2005.

76 'Kasus Tanjung Priok mulai disidangkan 15 September 2003', Kompas, September 5, 2003.

77 Surat Dakwaan, Sutrisno Mascung dkk, No. Reg.: 01/HAM/TJ.PRIOK/08/2003, on August 21, 2003.

78 Surat Dakwaan, Rudolf Adolf Butar Butar, No. Reg.: 01/HAM/TJ.PRIOK/09/2003, on September 8, 2003.

${ }^{79}$ Article 36, the Law on Human Rights Court No. 26 of 2000.
} 
not granted any reparation of compensation directed to victims, regardless whether the respected law asserts it otherwise and the Government Regulation No. 3 of 2002 has specifically set forth the entitlement to compensation, restitution, and rehabilitation for victims of gross violations of human rights. On appeal to the High Court, the judges voided the rulings of the Ad Hoc Court on Sutrisno Mascung CS and Rudolf Adolf Butar Butar and ordered the release of all defendants. Later on, the Supreme Court rejected the cassation appeal of the cases. ${ }^{80}$

During the procedure at the Ad Hoc Court, it appeared that serious flaws had been inhibiting the trial process. Criticisms led to the weakness of indictments, ${ }^{81}$ including the negligence of the principle of command responsibility. ${ }^{82}$ Additionally, it was also observed that the prosecutors were unable to provide credible evidence to support their indictments, as much evidence was no longer available or had been destroyed. Moreover, during the course of the trials, an atmosphere of intimidation, manifesting in the mobilization of military troops and officers attached to the Special Forces (Kopassus) to attend and to occupy the Court's seats, daunts not only the witnesses but also others including the prosecutors or even the judges. Some witnesses were reported to change their stories because they had made peace agreement, called the islah, with the military prior to the trials. ${ }^{83}$

Trials are a useful strategy for ending the culture of human rights violations in the past. It may give back the trust of the right-holders to human rights and at the same time empower them as they witness their sufferings being taken into account. Trials also have a deterrent effect, reducing the likelihood that similar things will happen in the future. Therefore, human rights trials need to meet their expectations; being powerful and independent in protecting victims and bringing their cases into justice. Failure in doing so will bring human rights implementation into stagnation, causing disrespect and distrust to the Court jurisdiction and discouraging human rights victims to bring their cases to the Court.

\section{Corruption in the Judicial System}

On March 15, 2008, the Anti-Corruption Court has sentenced Irawady Joenoes to a 400 million IDR (US\$4,400) fine and 8 years in prison, 2 years heavier than what the prosecutors demanded. ${ }^{84}$ Ironically, Joenoes, who was found guilty for accepting bribes in a land procurement deal, was a former member of the Judicial Commission, an independent institution that is tasked to select Supreme Court Justices, supervise judges, and monitor the judiciary's behavior and integrity. ${ }^{85}$ Presiding Judge Masrudin Chaniago said Joenoes had been proven to violate the Law on Corruption

\footnotetext{
${ }^{80}$ Kontras, Perkembangan Kasus Pelanggaran Ham Berat Tanjung Priok, Report, 2003.

${ }^{81}$ In their indictment, the prosecutors failed to include the important elements of 'systematic' and widespread in their description of the abuses perpetrated. They also did not cite the social and political setting of the time as important factors in conditioning the demonstrators to march in the streets against local military officers, leading to the killing Sulitiyanto (2007, loc.cit., p. 86-87).

82 'Indictment weak: Experts', The Jakarta Post, August 23, 2004.

${ }^{83}$ Sulitiyanto (2007, loc. cit., pp. 86-87).

84 “Judicial Watchdog Member Jailed for Accepting Bribes", The Jakarta Post, March 15, 2008.

${ }^{85}$ Article 24C, the Fourth Amendment of the 1945 Constitution.
} 
No. 31 of 1999 that authorizes the Anti-Corruption Court to penalize public officials to between 4 years and life in prison for accepting bribes.

The case shows how corruption is hovering on the promotion of the rule of law in Indonesia. In fact, corruption is considered the most common focus of attention in discussions regarding the Indonesian judicial reform. This errant practice can be found in many elements of the judicial system, including the police force, the attorney general's office, and the legal profession. It can also be found from the level of district court to the level of Supreme Court.

An efficient and honest Supreme Court is critical to ensure that human rights claims are regarded justly. The Supreme Court controls the activities of most other courts and thus determines both legal culture and the implementation of human rights. In Indonesia, unfortunately, the Supreme Court is far from effective. Its judges (with a few honorable exceptions) lack forensic skills and experience of effective adjudication. It notoriously suffers from institutionalized corruption and widespread incompetence (Lindsey 2001, p. 93).

Corruption in the judicial system is frequently blamed on the low salaries. Judges have little incentive to resist huge bribes. In addition to that, particularly in the lower courts, judges have no protection against a powerful and violent defendant. In most cases, the high-profile defendant will appeal to a higher court and be released without punishment, leaving the verdict made at the lower level meaningless. The aforementioned Tanjung Priok case describes exactly this situation. The rulings of the ad hoc human rights court at the first level were nullified by the higher courts. Therefore, in this type of cases, knowing well upfront that the defendant's appeal will be successful, judges avoid having to hand out any punishment and accept the bribes. They use a technicality to avoid making a ruling that could offend a powerful defendant or issue a suspended sentence.

Hitherto, despite numerous reports on bribery allegedly involving judges, the Supreme Court admitted that they have yet made significant records to bring most of them to justice. According to their recent report, out of 369 complaints the Supreme Court received from the public on alleged misconduct of court officials, 43 cases were completed, with no judges punished so far. In 2005, out of 317 complaints, 40 legal staff were handed administrative sanctions and no judges faced criminal charges or got fired, while in 2006, some 505 complaints resulted in 51 staff members being handed administrative sanctions. ${ }^{86}$ Nevertheless, the decision of the Anti-Corruption Court on Irawady Joenoes, as described earlier, signaled a slight prospect in eradicating corruption in the judicial system. In that particular case, the Anti-Corruption Court showed its commitment of carrying its task in combating corruption in Indonesia.

\section{Civil Society Organizations and Collective Actions}

The origins of the modern civil society organizations, popularly known in Indonesia as LSM or Lembaga Swadaya Masyarakat, can be traced to the 1920s, when many social and modern organizations were established in conjunction with the emergence

\footnotetext{
$\overline{86}$ 'Corrupt Legal Institutions Impede Graft Reforms', The Jakarta Post, 29 January 2008.
} 
of the nationalist movement in Indonesia (Hikam 1999, p. 219). The leaders of these early $\mathrm{CSOs}^{87}$ mostly came from the middle class and had modern education. Thus, the modern CSOs were characteristically urban-based organizations led by professionals with broad ideological bases, objectives, and membership. The fact that some of these organizations eventually transformed themselves into political parties only further demonstrates their nature. ${ }^{88}$

Regardless of the long history of collective actions based on civil society organizations, during the Suharto regime, people were perceived as an uncontrollable horde in order to justify the imposition of oppressive measures against them (Katjasungkana 2000, p. 263). The elites were easily intimidated by collective actions and were taking a defensive or paternalistic stand against the people. Collective actions organized by the people were considered oppositions and those who were involved became political targets. ${ }^{89}$ As a result, for example, workers and their unions, which have been actively involved in the human rights struggle, had to strategize their actions into more acceptable demands. They frequently tried to demand basic freedom and right to assemble and organize, but were usually forced simply to defend themselves and their livelihood (Törnquist 2004, p. 381). Thus, although actions persisted throughout the Suharto period, they never became a fundamental threat (Hadiz 2000, p. 15).

The main activity of CSOs in Indonesia is advocacy. With respect to the human rights subject, YLBHI (Yayasan Lembaga Bantuan Hukum Indonesia or Indonesian Legal Aid Foundation) and ELSAM (Lembaga Studi dan Advokasi Masyarakat) are the leading organizations that concentrate their work on promoting human rights. In the early 1980 s, some CSOs, especially the pro-democracy movement, started to fight for the recognition of civil and political rights. International actors and their ideas also sensitized Indonesian CSOs in relation to the issue of human rights and democracy, increasing ties and collaboration with international CSOs, particularly through the International CSOs Forum on Indonesian Development (INFID). The 1993 UN World Conference on Human Rights and its preparatory meeting in Bangkok seemed to provide a catalyst for a significant reshaping of CSOs ideology and resulted in a Joint Declaration on Human Rights by Indonesian CSOs for Democracy in the same year (Nomura 2007, p. 506).

According to an Indonesian sociologist, Meuthia Ganie-Rochman, there are several issues that relate to politics in general and human rights in particular advocated by the CSOs. These issues are freedom of assembly, freedom of speech, free and fair election, and rule of law (Ganie-Rochman 2002, pp. 106-121). ELSAM, for example, is particularly busy monitoring the Human Rights Court in Indonesia, as well as with their work on witness protection and compensation (ELSAM 2003). Besides giving legal aid, YLBHI also publishes annual research on the human rights situation in Indonesia.

\footnotetext{
${ }^{87}$ These early CSOs included Budi Utomo, Serikat Islam (SI), Taman Siswa, Muhammadiyah, Nahdlatul Ulama (NU), and other similar organizations.

${ }^{88}$ SI and NU became political parties, while Taman Siswa and Muhammadiyah have remained social organizations which focus on education and social and religious activities.

${ }^{89}$ For example, the unrest at the Indonesian Democratic Party (PDI) headquarters on July 27, 1996, in which supporters for Megawati, who refused to accept government's recognized party leader Soerjyadi, were attacked by the military. John H. McGynn (et al.), 2005, loc.cit., p. 287.
} 
Furthermore, Ganie-Rochman concludes that the advocated activism exercised by the Indonesian CSOs possesses several strategic characteristics, including choosing the court as their political arena, targeting legislation changes, and seeking support from international actors (Ganie-Rochman, loc. cit., p. 284; WALHI 1995). YLBHI in this regard is involved in assisting human rights victims in the domestic courts. These strategies are taken for safety and affective reasons. For the CSOs, political advocacy through the House of Representative body is considered risky and ineffective, simply because it is a governmental institution. The CSOs prefer to perform their advocacy with the help of media, through public meetings and seminars and with the formulation of CSO coalitions of specific objective. Because of these characteristics, generally the role of CSOs in promoting human rights in Indonesia is limited. Ganie-Rochman argues that the CSOs can only deliver political impact, whereas the fulfillment of human rights entitlements remains a government's business.

The transition of government has opened up unprecedented freedom, giving the people for the first time, amongst others, a liberty to organize themselves in the way they prefer (Ghoshal 2004, p. 506). After the resignation of Suharto, many CSOs were formed instantly as a result of favorable political conditions and the flow of funding at that time. In the mid-1990s, 7,000 CSOs were registered with the Ministry of Home Affairs and by 2002 the number reached 13,500, ${ }^{90} 90 \%$ of which receive funds and support from international donors.

In the beginning and during the transitional process of governance, at first it seemed as if collective actions based on civil society organizations have increased their significance in the political system. In reality, however, people actions are still insignificant in the political arenas. An example is found in the context of transition of government. In May 1998, collective actions that took the form of student movements, backed up by academics, CSOs, mass organizations, and political party's representatives and claimed themselves as a moral force, had triggered the end of the Suharto regime. Yet, despite of their popularity, their proposal on how to conduct the transition was ignored completely by the House of People's Representatives. ${ }^{91}$ A similar phenomenon occurred in the context human rights. In an effort to refute their alleged past human rights violations, the military force accused the National Human Rights Commission of being provoked while justifying irrelevant facts during their investigations. ${ }^{92}$ In the other case, strong influence of the elites also delays the judicial process concerning human rights violations. In the case of Semanggi, a human rights case involving the shooting of student activists, after 10 years it was still processed by the Office of Public Prosecutor. ${ }^{93}$

Moreover, several laws related to legal and political reforms are disincentive to promote collective actions in Indonesia. The laws that regulate the openness for the

\footnotetext{
90 This number does not include those CSOs that are not registered in the Ministry of Home Affairs, Kompas, 13 January 2003. Another data from the Central Statistic Bureau (Biro Pusat Statistic) provides the number of 10,000 CSOs in 1996 and 70,000 CSOs in 2000. "LSM sebagai Kekuatan Sosial Baru", Kompas, 17 April 2004.

${ }^{91}$ Katjasungkana (2000), loc. cit., p. 260.

92 'Purnawirawan TNI-Polri Kecam Komnas HAM'. Antara News, 24 April 2008, 'Ketua Komnas HAM: Kami Bekerja Sesuai UU', Kompas, 25 April 2008.

93 'Penegakan Hukum 10 Tahun Berlalu, Kejaksaan Masih Pelajari Kasus Pelanggaran HAM Berat', Kompas, 1 April 2008.
} 
people to be involved in the governance (for example, the Law on Election No. 3 of 1999 and the Law on Political Parties No. 31 of 2002) only focus on procedural and institutional solutions. They have not been directed at more substantial changes that can empower the civil society. A particular restriction to collective actions is stipulated in the new Law on Expressing Opinion No. 9 of 1998. This law, which was actually proposed by the military, asserts the requirement to submit a written report to the police before demonstrations.

Against this argument, collective actions in Indonesia remain in the weak state of leverage. In that regard, two prominent Indonesianist scholars, Vedi Hadiz and Richard Robinson, have argued that power relations in Indonesia have simply been reorganized since Suharto's fall rather than transformed (Rosser et al. 2005, p. 53). Suharto's regime was dominated by elites who occupy the state apparatus and criminal figures that had close connections to these individuals. Since then, they have been reinventing themselves through new alliances and vehicles.

Certainly, people are now having greater freedom to organize and engage in collective actions. However, their organizational capacity remains constrained. Civil society organizations that are able to represent the interest of the poor still complain about the same problems, namely those related to financial and organizational capacity. A massive increase in donor funding of CSOs has undeniably enabled some organizations representing the poor and disadvantaged groups expand and strengthen their organization structures and increase their lobbying activities, but many other organizations are lacking capabilities to manage funding or have insufficient knowledge and capabilities to take full advantage of emerging opportunities to influence policies related to human rights. Additionally, with the immense growing number of CSOs, their actions are overlapping and disperse, resulting in the inefficiency in taking their actions to the policy level.

Thus, although collective actions related to human rights experience different opportunities, indicated by more access to initiate actions, they still hold a weak bargaining position in influencing the human rights enforcement in Indonesia. The elements that were marginalized under Suharto such as the poor and disadvantaged have remained excluded from the policy-making process. The removal of the lid on politics has left no significant changes for collective actions to actually deliver positive improvement in the promotion of human rights that has an actual impact on the people.

\section{Final Remarks}

Since the beginning of Indonesia's independence, human rights have been perceived as complicated issues in legal and political arenas. The discussion of Indonesian legal system and the proliferation and interpretation of human rights highlight that the legal protection of human rights was decided upon compromises, ranging from introducing a countermeasure against human rights, which is human responsibility, to adjusting responses according to international pressures. Subsequently, these compromises have not significantly advanced the actual protection and promotion of human rights.

After the New Order's collapse, human rights discourses were being explicitly incorporated in the legal system, followed by ratifications of important human rights documents. These new commitments have attached 
the government with legal obligations at the policy level. Human rights have become claimable. The right-holders can now use human rights to claim their entitlements using political and legal actions, particularly as new human rights institutions and responsible actors are installed. In that regard, on paper, Indonesia has come a long way since the days of Suharto. This article has examined some of these significant developments, which should be setting the foundations for the promotion of human rights in Indonesia.

In reality, somehow legal and/or political commitment is no guarantee of effective action. Human rights enforcement remains a problematic subject. The adoption of human rights certainly changes the relationship between the state and the people, particularly with regard to openness of the government of collective actions both initiated by people and civil society organizations. It also gives freedom for the media to broadcast or publish news related to errant practices in the governmental level or human rights violations.

However, even when the people are now more aware of their human rights entitlements and have taken legal or political action, only poor standard actions have been taken by the government to advance the actual command and access for claiming human rights entitlements. The government continues to adopt laws that are riddled with loopholes. Furthermore, the quality of human rights institutions is inadequate that promotion of human rights has no direct impact on changing society and protecting people's human rights. Reform of all these institutions has been on the agenda for years, but hitherto enforcement has been ineffective and unenthusiastic. The lack of measures taken to eradicate these substantial and institutional problems makes the incorporation of human rights principles in the Indonesian legal system meaningless. Additionally, the human rights promotion revolves around the safe topics without real substantial improvement in the actual freedoms that are closely related to people. These deficits demonstrate that the use of human rights jargon is not enough, unless they are translated into tangible reform on policies and institutions.

The enforcement of human rights in Indonesia is centered on a dialog-based approach, rather than a violation-based approach. The adoption of human rights discourse in the legal system serves as revealing violations and opening a dialog between human rights agents and victims, rather than actually guarantee law enforcement through punishment. In this context, human rights in Indonesia has yet achieved the status as legal resources that can guarantee protection and retribution. Nevertheless, for victims and civil society organizations, human rights are employed as a political instrument, carrying merely values of, rather than actual, change and empowerment. At the international context, the country's attempts to honor human rights by ratifying important human rights documents can be considered as an effective political strategy. Indonesia's primary motivation throughout accepting international commitments has been merely to pre-empt international action and protect national interest and sovereignty. The series of formal ratification of international human rights documents and the establishment of human rights implementation bodies have established a good international reputation for Indonesia. Ratifications and establishment are politically motivated as it can block further pressures on actual implementation. Therefore, in the case of Indonesia, the government has been taking a defensive enforcement approach in promoting human rights. 
Open Access This article is distributed under the terms of the Creative Commons Attribution Noncommercial License which permits any noncommercial use, distribution, and reproduction in any medium, provided the original author(s) and source are credited.

\section{References}

A.A. Annaim, 'Human Rights and the Culture of Relevance: The Case of Collective Rights', in M. Casterman-Holleman et al, The Role of the Nation States in 21 Century: Human Rights, International Organisation and Foreign Policy. (The Hague: Kluwer International, 1998) p. 8.

Budiman, Arief (1978) Student Movement in Indonesia: A Study of the Relationship between Culture and Structure. Asian Survey 18: 609-625

Arief Budiman, 'Mythology and Ideology in Indonesia', Indonesia in the Soeharto Years, (Leiden: KITLV, 2005) p. 376

Bowen, John R. (1986) On the Political Construction of Tradition, Gotong Royong in Indonesia, Journal of Asian Studies 45: 545-561

Bas de Gaay Fortman, Persistent Poverty and Inequality in an Era of Globalisation: Implications of a Rights Approach, in Paul van Seters, Bas de Gaay Fortman and Arie de Ruijter (eds), Globalization and Its New Divides: Malcontents, Recipes, and Reform. (Amsterdam: Dutch University Press, 2003) p. 156.

de Gaay Fortman, Bas (2006) 'Human Rights', In David A. Clark, The Elgar Companion to Development Studies. UK, Edward Elgar Pub. LtD, pp. 260-266

Shafiq Dhanhani and Iyanatul Islam, "Poverty, Vulnerability, and Social Protection in Period of Crisis", World Development ,Vol. 30, No. 7, pp. 1213-1214, 2002.

Diehl, Paul F. et al (2003), 'The Dynamics of International Law: The Interaction of Normative and Operating Systems', International Organisation 57: p. 43-75

ELSAM, Kegagalan Leipzig Terulang di Jakarta, Catatan Akhir Pengadilan Ad Hoc Timor-Timor, 9 September 2003, http://www.elsam.or.id/pdf/FinalAssesmentAdHocTimor.pdf, accessed 30 May 2007 , at 17.06 .

Meuthia Ganie-Rochman, An Uphill Struggle: Advocacy NGOs under Suharto's New Order, (Depok: Lab Sosio FISIP UI, 2002) pp. 106-121.

Yash Ghai, 'Human Rights and Governance: The Asian Debate', Asia Pacific Journal of Human Rights and the Law 2000, 1, p. 16-25

Ghoshal, Baladas (2004) Democratic Transition and Political Development in Post-Soeharto Indonesia. Contemporary South East Asia 26: 506-529

Jurgen Haberman, Between Facts and Norms. (Massachusetts: MIT Press, 1996) p. 159.

Jurgen Habermas, 'Remarks on Legitimation through Human Rights', the Postnational Constellation, Political Essays (Massachusetts: MIT Press, 2001) p. 113.

Nursyahbani Katjasungkana, 'Exchanging Power or Changing Power? The Problem of Creating Democratic Institutions', in Chris Manning et.el, Indonesia in Transition: Social Aspect of Reformasi and Crisis (Singapore: ISEAS, 2000) p. 263

Hadiz, Vedi R. (2000) Retrieving the Past or the Future? Indonesia and the New Order Legacy. South East Asian Journal of Social Science 28: 10-33

Andrew Halpin, Rights and Laws and Analysis of Theory. (Oxford: Hart Pub., 1997) p. 90.

Hikam, Muhammad A.S. (1999) 'Non-Governmental Organisation and the Empowerment of Civil Society’. In Richard W. Baker, et. al., Indonesia the Challenge of Change. Leiden, KITLV Press, pp. 217-232

Hosen, Nadirsyah (2002) Human Rights and Freedom of Press in the Post Suharto Era. Asian Pacific Journal on Human Rights and Law 3: 1-104

Ignatieff, M. (2001) Human Rights as Politics and Idolatry. New Jersey: Princeton Univ. Press

Juwana, Hikmahanto (2006) 'Human Rights in Indonesia'. In Randall Peerenboom et.al. (eds), Human Rights in Asia: A Comparative Legal Study of 12 Asians Jurisdictions, France, and the USA, New York: Routledge, pp. 364-383

Lindsey, Tim (2001) Unraveling the New Order? Recent Developments in Indonesia Law Reform. European Journal of Law Reform 3: 89-101

Magnis-Suseno, Franz (2001) Etika Jawa, Sebuah Analisa Falsafi tentang Kebijaksanaan Hidup Jawa. Jakarta, Gramedia 
Morfit, Michael (1981) Pancasila: The Indonesian State Ideology According to the New Order Government. Asian Survey 21: 838-851

Ko Nomura, 'Democratisation and Environmental Non-Governmental Organisation in Indonesia', Journal of Contemporary Asia, Vol. 37, No. 4, November 2007, p. 506

Pratikno and Cornelius Lay, 'Komnas Ham dan Ham di Bawah Rejim Otoritarian', Journal Ilmu Social dan Ilmu Politik. 2 (1999) p. 7.

Priyambudi Sulitiyanto, 'Politics of Justice and Reconciliation in Post-Suharto Indonesia, Journal of Contemporary Asia, Vol. 37, No. 1 February 2007, p. 78

Pye, Lucian W. (1999) Civility, Social Capital, and Civil Society: Three Powerful Concepts for Explaining Asia. Journal of Interdisciplinary History 29: 763-782

Joseph Raz, 'Legal Rights', Oxford Journal Legal Study 4 (1984) p. 5.

Risse, Thomas (1999) International Norms and Domestic Change: Arguing and Communicative Behaviour in the Human Rights Area. Politics and Society 27: 529-559

Roth, Kenneth (2004) Defending Economic, Social, and Cultural Rights: Practical Issues Faced by International Human Rights Organisations. Human Rights Quarterly 26: 63-73

Rosser, Andrew et.al. (2005) Indonesia: the Politics of Inclusion. Journal of Contemporary Asia 35: 53-77

M. Sepulveda, The Nature of the obligations under the International Covenant on Economic, Social and Cultural Rights, School of Human Rights Research Series, Utrecht University, (Antwerp: Intersentia, 2003).

T. Simanjuntak, 'Government, DPR drag their feet in supporting human rights', The Jakarta Post, 4 March 2002.

Törnquist, Olle (2004) Labour and Democracy? Reflections on the Indonesian Impasse. Journal of Contemporary Asia 34: 377-399

WALHI, Kasus Rakyat Jelmu Sibak Melawan Bob Hasan, Jakarta: Unpublished Case Report, 1995.

Wanandi, Jusuf (1993) Human Rights and Democracy in the ASEAN Nations: the Next 25 Years. The Indonesian Quarterly 21: 14-37

Alan White, Rights. (Oxford: Clarendon Press, 1984) p. 115. 